\title{
EVALUATION OF SOME NATURAL SUBSTANCES AGAINST VARROA DESTRUCTOR INFESTING HONEYBEE, APIS MELLIFERA IN EGYPT
}

\author{
GHADA S. REFAEI
}

Plant Protection Research Institute, ARC, Dokki, Giza

(Manuscript received 3 November 2010 )

\begin{abstract}
This study was conducted to investigate the effect of certain natural substances against Varroa mite. Four natural substances (Apiguard and Thyme, Camphor and Basil oils) were evaluated in the field as control agents against the parasitic mite, $V$. destructor. Four treatments of each tested material were applied to each colony during the treatment period. . Data showed that all four tested compounds were effective in controlling Varroa and Apiguard was the most effective substance as they had an efficiency of $81.3 \%, 74.6 \%, 71 \%$ and $67 \%$, respectively.
\end{abstract}

\section{INTRODUCTION}

Varroa destructor is considered one of the most serious pests affecting honeybee, $A$. mellifera on a worldwide basis, causing weight loss, malformation, and a shortened life span. It also serves as a vector of diseases that may lead to $100 \%$ bee mortality (Kanga and James, 2002). Chemical control using acaricides are still used to reduce mite populations in beehives, including Coumaphos, Apistan, Amitraz, Folbex, Folbex-Forte, Apitol and Sinecar (Henderson, 1988, Martin, 1994, Gregorc and Poklukar, 2003). These acaricides have significant drawbacks including contamination of honey, wax, and pollen (Calderone and Spivak, 1995), additionally resistant strains can be developed (Elzen et al., 1999). Consequently, natural components might offer promising new avenues for the beekeeping industry. Many studies had been carried out using some extracts of natural essential oil of various plants such as rosemary, lemongrass, camphor, clove, ginger roots, fennel and eucalyptus (Gregorc and Poklukar, 2003: Batish et al., 2008). Other scientists investigated the effectiveness of Apiguard and some organic acids (Bacandritos et al., 2007). Therefore, this study was conducted to evaluate the use certain essential oils and Apiguard as alternative control methods that are safe, and environment friendly, against the parasitic mite, $V$. destructor.

\section{MATERIALS AND METHODS}

The present study was carried out in an apiary at Giza Governorate in March and April 2008. Fifteen colonies of the honeybee, $A$. mellifera were identified as 
being infested with $V$. destructor. Each colony consisted of 10 full-depth combs of worker bees and a queen. The colonies were divided into five equal groups. The first and second groups were treated with one of the following substance, Apiguard and Thyme, Thymus vulgaris, respectively, while the third and fourth groups were treated with camphor, Eucalyputs spp, and basil oils , Ocimum basilicum, the fifth group served as control. One application of the tested materials were applied weekly for four successive weeks (treatment period), using a filter paper (carrier) saturated with $5 \mathrm{ml}$ of each tested material and placed on the top of colonies. Apiguard was applied in tray (two times, 50g) at 2 weeks interval. Control colonies received the carrier only without any test material.

To monitor Varroa populations before and after treatments, a "sticky board" was pushed in all hives's bottom prior to each treatment under the wire/wood frame, where falling mites were trapped and the wire kept bees from removing them (Sammataro et al., 1998). These boards were removed, replaced by new ones daily and the trapped mites were counted. The hive entrances remained open during the experiment and applications were carried out after sunset, when all honeybees had returned to the hives. Surviving mites remaining in each colony after treatment period were killed by using formic acid $(85 \%)$ for two consecutive weeks (treatment evaluation period) and counted.

The number of mites collected after each application was recorded and the efficiency percentage of each application of these compounds was determined.

The efficiency of each application was determined according to the formula of Colin (1990)

$$
X_{n}(\%)=\frac{A_{n} \times 100}{Z---------}
$$

$A_{n}$ : number of mites collected throughout the days following each application, $Z$ : total number of collected mites [mites collected after 4 applications + remaining mites collected after treatment evaluation period], and $\mathrm{Z}_{\mathrm{n}-1}$ : number of collected mites before each application.

Data obtained in the Varroa control groups were analyzed statistically using analysis of variance (ANOVA) and means were separated by a least significant differences test in SAS. 


\section{RESULTS AND DISCUSSION}

Table (1) indicated that the mean number of mites collected from the colonies that received four applications of the Apiguard (during the treatment period) was significantly higher (151.3 mites) than those that have received thyme, camphor and Basil oils (117.6, 113 and 98 mites/ hive, respectively). The mean efficiency percentage of Apiguard was significantly higher $(81 \pm 3.2)$ than thyme, camphor and

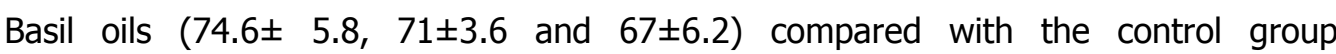
$(14.6 \pm 3.7)$ at $5 \%$ significant levels.

Honeybee, Apis mellifera is considered one of the most important and beneficial insects, whose damage has serious negative economic implications for both beekeeping industry and agriculture (Melathopoulos et al., 2000). In the present study, several natural substances were used as they are biodegradable, safe for human and relatively inexpensive, for the control of Varroa destructor.

Several authors have evaluated essential oils and their components as control agents for Varroa (Sammataro et al., 1998, Imdorf et al., 1999, Ariana et al., 2002 and Ismail et al., 2006), and indicated that many of these compounds are biologically toxic to Varroa without injuring bees. However, significant bee mortality was reported when powdered thymol was used against $V$. destructor, which was probably a consequence of the high surface area of thymol or high ambient temperatures (Chiesa, 1991 and Gal et al. 1992). Calderone (1999) indicated that Apistan is more effective than thymol-based blend. Therefore, numerous factors contribute to the overall efficacy of acaricides such as the concentration of compounds, delivery method, ambient temperature, and colony and apiary environment (Calderone and Spivak, 1995). On the other hand, Apiguard reduced Varroa mite populations on honeybees. There is no indication that this compound has adverse effects on the bees, where no apparent increases in number of dead bees at hive bottoms. Similarly, several authors have evaluated this compound as control agent for Varroa destructor mite (Mattila et al., 2000, Emsen and Dodologlu, 2009). In addition, May-Itza et al., (2007) indicated that the Apiguard (thymol gel) could eliminate 95\% of the mites in honeybee colonies under tropical conditions and thus could be used as an alternative method for controlling this parasite.

Generally, using natural substances to control Varroa mites in recent years, support the need to overcome resistance issues with currently registered acaricides. 
Table 1. Results of field evaluation of different natural extracts against Varroa mite

\begin{tabular}{|c|c|c|c|c|c|c|c|c|c|c|c|}
\hline \multirow[t]{2}{*}{ Group } & \multirow[t]{2}{*}{ Colony } & \multicolumn{4}{|c|}{$\begin{array}{c}\text { Number of collected } \\
\text { mites after indicated } \\
\text { applications : } \\
\end{array}$} & \multirow[t]{2}{*}{ AT } & \multirow[t]{2}{*}{ M } & \multirow[t]{2}{*}{ B } & \multirow[t]{2}{*}{ z } & \multirow[t]{2}{*}{$x_{n}$} & \multirow[t]{2}{*}{$\mathrm{M} \pm \mathrm{SD}$} \\
\hline & & $1 \mathrm{st}$ & 2nd & $3 r d$ & 4th & & & & & & \\
\hline \multirow[t]{3}{*}{ Apiguard } & 1 & 41 & 23 & 35 & 17 & 116 & & 21 & 137 & 85 & \multirow{3}{*}{$81.3 \pm 3.2$} \\
\hline & 2 & 67 & 59 & 39 & 26 & 191 & 151.3 & 49 & 240 & 80 & \\
\hline & 3 & 55 & 46 & 30 & 16 & 147 & & 38 & 185 & 79 & \\
\hline \multirow[t]{3}{*}{ Thyme } & 1 & 28 & 49 & 10 & 13 & 100 & & 46 & 146 & 68 & \multirow{3}{*}{$74.6 \pm 5.8$} \\
\hline & 2 & 51 & 38 & 27 & 26 & 142 & 117.6 & 37 & 179 & 79 & \\
\hline & 3 & 49 & 22 & 19 & 21 & 111 & & 33 & 144 & 77 & \\
\hline \multirow[t]{3}{*}{ Camphor } & 1 & 27 & 34 & 18 & 10 & 89 & & 34 & 123 & 72 & \multirow{3}{*}{$71 \pm 3.6$} \\
\hline & 2 & 48 & 36 & 39 & 25 & 148 & 113 & 51 & 199 & 74 & \\
\hline & 3 & 30 & 32 & 29 & 11 & 102 & & 50 & 152 & 67 & \\
\hline \multirow[t]{3}{*}{$\begin{array}{l}\text { Basil } \\
(50 \%) \\
\end{array}$} & 1 & 42 & 25 & 16 & 7 & 90 & & 47 & 137 & 65 & \multirow{3}{*}{$67 \pm 6.2$} \\
\hline & 2 & 18 & 25 & 12 & 11 & 66 & 98 & 40 & 106 & 62 & \\
\hline & 3 & 33 & 49 & 27 & 29 & 138 & & 48 & 186 & 74 & \\
\hline \multirow[t]{3}{*}{ Control } & 1 & 18 & 13 & 10 & 8 & 49 & & 189 & 238 & 19 & \multirow{3}{*}{$14.6 \pm 3.7$} \\
\hline & 2 & 13 & 4 & 6 & 2 & 25 & 35 & 154 & 179 & 13 & \\
\hline & 3 & 8 & 10 & 6 & 7 & 31 & & 171 & 202 & 12 & \\
\hline
\end{tabular}

AT: Number of collected mites after the treatment period

$B$ : Number of mites remaining in colonies after the 4 applications (treatment evaluation period)

Z: Total number of mites in each colony $(A T+B)$

$\mathrm{Xn}$ : Percentage of Efficiency of the treatments after the four applications

M: Mean

\section{REFERENCES}

1. Ariana, A., R. Ebadi and G. Tahmasebi. 2002. Laboratory evaluation of some plant essences to control Varroa destructor (Acari: Varroidae). Exp. Appl. Acarol., 27(4): 319-327.

2. Bacandritos, N., I. Papanstasiou, C. Saitanis, A. Naetti and E. Roinioti. 2007. Efficay of repeated trickle applications of oxalic acid in syrup for varroasis control in Apis mellifera: Influence of meteorological conditions and presence of brood. Vet. Parasitol., 148: 174-178.

3. Batisha, D.R., H.P. Singh, R.K. Kohli and S. Kaur. 2008. Eucalyptus essential oil as a natural pesticide. For. Ecol. Manage., 256: 2166-2174. 
4. Calderone, N.W. 1999. Evaluation of formic acid and a thymol-based blend of natural products for the fall control of Varroa jacobsoni (Acari: Varroidae) in colonies of Apis mellifera (Hymenoptera: Apidae). J. Econ. Entomol., 92(2): 253260.

5. Calderone, N.W. and M. Spivak. 1995. Plant extracts for control of the parasitic mite, Varroa jacobsoni (Acari: Varroidae) in colonies of the western honeybee (Hymenoptera: Apidae). J. Econ. Entomol., 88(5): 1211-1215.

6. Chiesa, F. 1991. Effective control of varroatosis using powdered thymol. Apidologie, 22(2): 135-145.

7. Colin, M.E. 1990. Essential oils of Labiatae for controlling honeybee varroasis. J. Appl. Entomol., 110: 19-25.

8. Elzen, P.J., F.A. Eischen, J.R. Baxter, G.W. Elzen and W.T. Wilson. 1999. Detection of resistance in US Varroa jacobsoni Oud. (Mesostigmata: Varroidae) to the acaricide Fluvalinate. Apidologie, 30: 13-17.

9. Emsen , B and A. Dodologlu. 2009. The Effects of Using Different Organic Compounds against Honey Bee Mite (Varroa destructor Anderson and Trueman) on Colony Developments of Honey Bee (Apis mellifera L.) and Residue Levels in Honey. Journal of Animal and Veterinary Advances. (8), 1004-1009.

10. Gal, H., Y. Slabezki, and Y. Lensky. 1992. A preliminary report on the effect of origanum oil and thymol applications in honeybee (Apis mellifera L.) colonies in a subtropical climate on population levels of Varroa jacobsoni. Bee Sci., 2(4): 175180.

11. Gregorc, A. and J. Poklukar. 2003. Rotenone and oxalic acid as alternative acaricidal treatments for Varroa destructor in honeybee colonies. Vet. Parasitol., 111: 351-360.

12. Henderson, C. 1988. Tests of chemical control agents for Varroa jacobsoni in honeybee packages. pp. 380-386. In: G.R. Needham, R.E. Page, Jr. M. DelfinadoBaker and C. Bowman (eds.), Africanized Honeybees and Bee Mites, E. Horwood, Chichester.

13. Imdorf, A., S. Bogdanov, R.I. Ochao and N.W.Calderone. 1999. Use of essential oils for the control of Varroa jacobsoni Oud. in honeybee colonies. Apidologie, 30(2-3): 209-228.

14. Ismail,A. M., A. H. Ghoniemy and A. A. Owayss. 2006. Combatting honeybee Varroa mites by plant oils alone or in an IPM program. The 2nd conference of Farm Integrated Pest Management, 16-18 Jan., Fac. Agric., Fayoum Univ., 172-185 pp., 2006 
15. Kanga, L.H. and R.R. James. 2002. Varroa control with fungal pathogens may be an option soon. Amer. Bee J., 142(7): 519-520.

16. Martin, S.J. 1994. Ontogensis of the mite Varroa jacobsoni Oudemans in worker brood of the honeybee Apis mellifera L. under natural conditions. Exp. Applied Acarol., 18: 87-100.

17. May-Itza, W.J., L.A. Medina and J.C. Marrufo Olivares. 2007. Effectiveness of thymol based jells for the control of Varroa destructor mite that infests Apis mellifera honey bee colonies, under tropical conditions in Yucatan, Mexico. Vet. Mex., 38(1), 1-8

18. Melathopoulos, A.P., M.L. Winston, R. Whittington, T. Smith, C. Lindberg, A. Mukai and M. Moore. 2000. Comparative laboratory toxicity of neem pesticides to honeybees (Hymenoptera: Apidae), their mite parasites Varroa jacobsoni (Acari: Varroidae) and Acarapis woodi (Acari: Tarsonemidae), and brood pathogens Paenibacillus larvae and Ascophaera apis. J. Econ. Entomol., 93(2): 199-209.

19. Mattila, H.R., G.W. Otis, J. Daley and T. Schulz. 2000. Trials of Apiguard, a thymol based miticide. Part 2. Non-target effects on honeybees. American Bee Journal, 140: 68-70.

20. Sammataro, D., G. Degrandi-Hoffman, G. Needham and G. Wardell. 1998. Some volatile plant oils as potential control agents for Varroa mites (Acari: Varroidae) in honeybee colonies (Hymenoptera: Apidae). Am. Bee J., 138(9): 681-685. 


\section{تأثير بعض المواد الطبيعة على طفيل الفاروا}

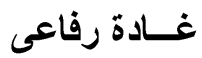

$$
\text { معرة بحوث وقاية النباتات - الدقى - الجيزة }
$$

يعتبر طفيل الفـــاروا من اخطر الطفيليات التي تصيب نحل العسل و تشبب الكثير من الأضر ار لصناعة نحل العسل ومنتجاته المتتوعة. من هنا إهتمت هذه الدر اسة بإقتر اح طرق و أساليب

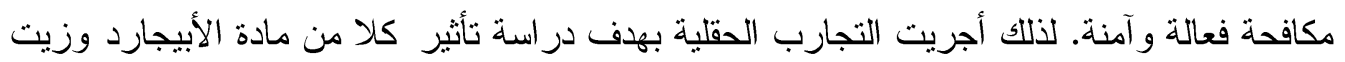
الزعتر ، الكافور و البردقوش فى مكافحة طفيل الفارو ا ـ حيث تمت معاملة خلايا نحل العسل المصابة بطفيل الفاروا 4 مرات طو ال فترة التجربة، وفى كل الخلايا تم فحص وتقدير عدد الأكاروسات الميتة المتو اجدة أسفل كل خلية على حدة وكذلك حساب كفاءة هذه المو اد . . وقد اوضحت نتائج هذه الدر اسة أن كل هذه المعاملات كانت فعّالة معنويا ضد الفارو ا فى الطو ائف المعاملة مقارنة بالغير معاملة حيث وصلت كفاءة مادة الأبيجارد فى خفض طفيل الفاروا إلى 81.3 \% بينما بلغت كفاءة المو اد الأخرى

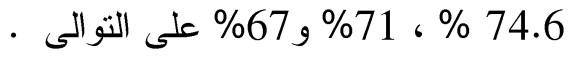

